UDC 336.22:338.2:338.43

DOI: https://doi.org/10.32847/business-navigator.60-16

\author{
Koptieva Olha \\ Postgraduate Student of the Department of \\ Accounting and Business Consulting \\ Simon Kuznets Kharkiv National University of Economics
}

Коптсва О.В.
аспірант кафедри обліку і бізнес-консалтингу
Харківський національний економічний університет
імені Семена Кузнеця

\title{
THE ESSENCE, CLASSIFICATION AND ROLE OF TAX STIMULUS FOR ACTIVATION OF INNOVATIVE PROCESSES IN AGRICULTURE
}

Koptieva Olha. The essence, classification and role of tax stimulus for activation of innovation processes in agriculture. The paper is devoted to essential problems of tax stimulation of innovative activity in agriculture. The paper grounds the economic understanding of the concept "tax stimulus" and reveals peculiarities of tax stimuli for innovations. The paper investigates complex of economic tools for tax stimulation of innovative activity and discusses the classification of tax stimuli. The paper also justifies basic principles of an effective tax stimulation system based on deep review of best international experience and examination of national practice. The paper concludes about inefficient tax stimulation mechanism for innovations at agricultural companies in Ukraine and substantiates proposals for enriching national tax system to enable flexible stimulation depending on business features and stages of innovation process.

Key words: innovative activity, national tax system, tax stimulus, agriculture, tax preferences.

Коптєва О.В. Сутність, класифікація та роль податкових стимулів щодо активізації інноваційних процесів в сільському господарстві. В умовах жорстокої економії коштів державного бюджету особливого значення набувають заходи непрямої підтримки інноваційної діяльності. Систематичне впровадження науково обгрунтованих державних заходів непрямого стимулювання інноваційної діяльності дасть змогу мінімізувати негативний вплив структурних диспропорцій у джерелах фінансування інноваційної діяльності в Україні. Для успішного вирішення питання активізація інноваційних процесів в сільському господарстві є запровадження дієвого механізму податкового стимулювання, що б сприяло формуванню належного інвестиційного забезпечення інноваційних проектів. Дана стаття присвячена розгляду актуальних проблем податкового стимулювання інноваційної діяльності у сільському господарстві. У статті представлено обгрунтування та розмежування схожих понять до терміну «податковий стимул», узагальнено його характерні ознаки. Обгрунтовано економічне розуміння поняття «податковий стимул» та розкрито особливості податкового стимулювання інновацій. Досліджено комплекс економічних інструментів податкового стимулювання інноваційної діяльності та розглянуто класифікацію податкових стимулів. Стаття також обгрунтовує основні принципи ефективної системи податкового стимулювання на основі детального дослідження кращого міжнародного досвіду та вивчення національної практики. На основі аналізу податкового законодавства щодо стимулювання суб'єктів інноваційної діяльності зроблено висновок про неефективний механізм податкового стимулювання інновацій на сільськогосподарських підприємствах України, головними причинами є: недосконале податкове законодавство, зловживання пільговими умовами деякими суб'єктами інноваційної та інвестиційної діяльності; значні бюджетні витрати. У статті доведено, що сільськогосподарські підприємства функціонують в єдиному податковому середовищі, що не враховує рівень їх залучення в інноваційний процес та обгрунтовано пропозиції щодо збагачення національної податкової системи для забезпечення гнучкого стимулювання залежно від особливостей бізнесу та стадій інноваційного процесу.

Ключові слова: інноваційна діяльність, національна податкова система, податковий стимул, сільське господарство, податкові преференції.

Коптева О.В. Сущность, классификация и роль налоговых стимулов для активизации инновационных процессов в сельском хозяйстве. Статья посвящена рассмотрению актуальных проблем налогового стимулирования инновационной деятельности в сельском хозяйстве. В статье обосновано экономическое понимание понятия "налоговый стимул” и раскрыты особенности налогового стимулирования инноваций. В статье исследован комплекс экономических инструментов налогового стимулирования инновационной деятельности и рассмотрена классификация налоговых стимулов. Статья также обосновывает основные принципы эффективной системы налогового стимулирования на основе детального исследования лучшего международного опыта и изучения национальной практики. В статье сделан вывод о неэффективном меха- 
низме налогового стимулирования инноваций на сельскохозяйственных предприятиях Украины и обоснованы предложения по обогащению национальной налоговой системы для обеспечения гибкого стимулирования в зависимости от особенностей бизнеса и стадий инновационного процесса.

Ключевые слова: инновационная деятельность, национальная налоговая система, налоговые стимулы, сельское хозяйство, налоговые преференции.

Problem statement. Significant support for innovative businesses is gaining popularity among the governments of highly developed countries, as innovation in the modern world is the significant basis for sustainable development and competitiveness of business. However, despite the formation of an innovative model of economic development in Ukraine, its obvious characteristic is the lack of active innovations. During the long period of reforming innovation policy, the Ukrainian government has not taken significant and effective measures to stimulate innovation, especially in the agrarian sector. So, the development of a tax mechanism adapted to modern economic conditions, which would reduce the tax burden on agricultural producers, save their money and thus increase interest in introducing innovations, is essential for theory evolution and practice problems solution.

Analysis of recent researches and publications. A thorough literature review reveals that many foreign and Ukrainian scholars devoted their publications to the problems of tax regulation and stimulating of innovations, especially: Gureev V., Ivanov Yu. [8], Krysovatyi A. [9], Maiburov I., Masiuchenko E., Naidenko O., Tarangul L. Peculiarities of innovation activity, national and international problems of its regulation are discussed in publications of Labunska $\mathrm{S}$. [12; 13], Karaszewski R. [12], Prokopishyna O. [12-14], Iermachenko I. [12], Petrova M. [13].

However, modern science has not sufficiently studied the mechanism of tax stimulation for innovation yet, and the choice of tools for tax stimulation for innovation of agricultural enterprises deserves further in-depth study.

Task statement. The purpose of the paper is to study the theoretical foundations and develop scientific and practical recommendations for improving the tools of tax stimulation for innovation, taking into account the peculiarities of national regulation of agricultural business.

The statement of the basic material. The analysis of the modern legal framework for stimulating the innovative development of the national economy shows that innovation companies for the implementation of innovative projects may apply mainly for limited state financial support. However, small and medium-sized agricultural enterprises may not have large innovation ambitions and innovation development strategies, and therefore they find it difficult to compete with large vertically integrated agricultural companies for direct state financial support. And that is why tax stimulation for innovation seems to be the most universal tool of state support, as it equates the conditions for all possible participants in innovation, regardless of their size, experience and form of ownership.

It is known that taxes are a determining factor in the development of production, and their dual impact on production is manifested in the fact that, on the one hand, the payer of a certain part of their income in the form of tax reduces its financial, including innovative, opportunities, and thus inhibits the development of production. At the same time, taxes can have a stimulating effect on the devel- opment of business. We consider constructive the proposals of D. Reva, who notes that "stimulus component of taxation works only when the state guarantees the taxpayer that it will not declare its rights to all its profits obtained by reducing production costs. Otherwise, the payer will not be interested in increasing productivity and expanding production" $[1$, p. 73$]$.

In Ukraine, the study of tax stimulus for innovative economic development is based, on the one hand, on the justification and selection of tax regulation methods through the assessment of the impact of tax stimulus on the efficiency of Ukraine's economy; on the other hand, on the analysis of foreign experience in innovative economic development with the help of appropriate tax instruments [2, p. 34].

From a theoretical point of view, one of the key tasks of the study is to determine the essence of the concept of "tax stimulus", identify its characteristics and form a complete classification of all possible types. Of course, these tasks are not the only one but they are the most important for understanding the essence of the subject and further, much deeper, study of the mechanism of tax stimulation of innovation in agriculture.

In general, stimulus is a thing or event that evokes a specific functional reaction. So, stimulus (from Latin stimulus is literally a pointed stick, which drove the animals) is an incentive that causes a reaction, motivation to action [3, p. 58]. The essence of the concept of "stimulus" may also be seen as an interest in doing something. Synonyms of this concept are activation, motivation, encouragement, impulse. It may be proposed to understand economic stimulation as the excitation of entities (producers, consumers, buyers) by economic incentives to behave in a way that the actor of stimulation may benefit from. Then tax stimulation is proposed to define as the process of excitation of market actors, conducted by central and local governmental institutions, through application of tax stimuli that encourage market actors to behave in a way that national economic, social and/or environmental system may benefit from.

In the international researches and publications, the "tax stimulus" is identified with the concepts of "tax benefit", "tax preference", "tax subsidies" quite often. Therefore, it is necessary to establish the relationship between these terms and distinguish concepts depending on their characteristic properties (Figure 1).

In the literature, the stimulus is seen as an incentive to action, a condition for the development of something. Such activity is caused by the specific interests of specific actors. Interest becomes an intense catalyst for human activity only when there is a real possibility of its satisfaction. When a subject has a choice between several behaviors, his or her interest turns to a more useful option. The tax stimulus is necessarily incentive, which distinguishes it from benefits, preferences, advantages or subsidies.

Unlike tax subsidies, tax stimulus may not be in the nature of monetary or financial support. A clear example 


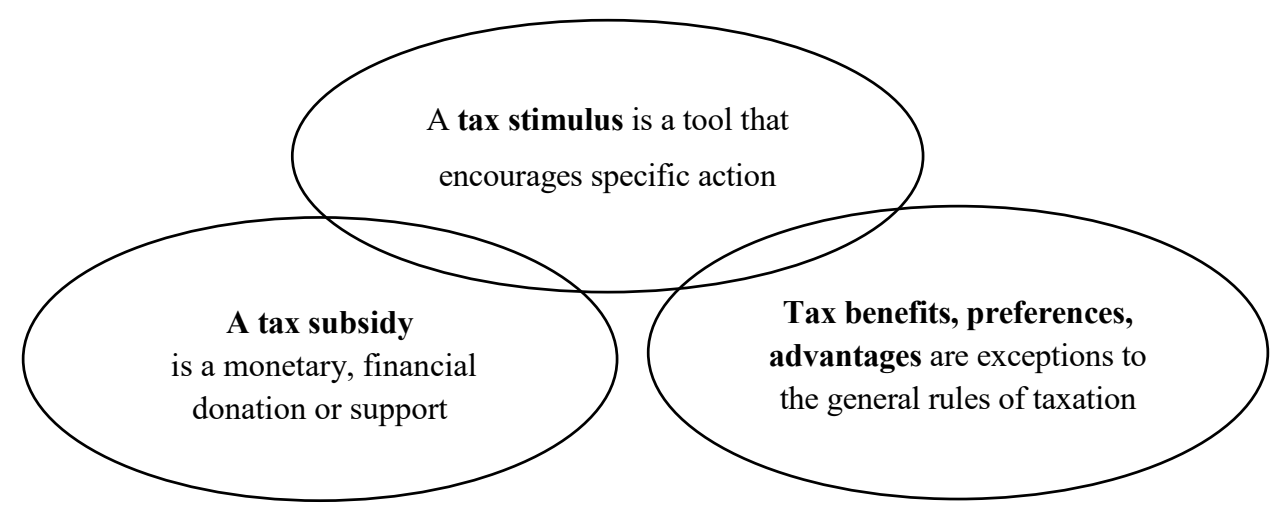

Figure 1. The distinct features of tax stimulus, subsidies and benefits

of this is the free of charge state informing the taxpayer. Since a taxpayer who is aware of government initiatives in the field of taxes and fees is able to respond to them to a greater extent, such an instrument to some extent affects his behavior, therefore, can be called a tax stimulus.

Foreign experience shows that the information work of tax authorities on the provision of tax benefits for R\&D takes place at all stages of obtaining benefits. Thus, before submitting an application, the tools of the tax services are newsletters, self-assessment tools, seminars, publication of draft changes; after submitting the application until the end of the review - conducting seminars, setting standards for review; after the review - monitoring and publication of statistics.

It should be noted that the tax stimulus, in contrast to the tax benefit (tax preference, tax advantage), may not violate the principle of equality of the tax burden for taxpayers, i.e. the characteristic feature of the tax stimulus is not mandatory selectivity (because they can be directed as a separate group of taxpayers, for certain activities or be common to all). Thus, the introduction of a simplified tax regime for agricultural enterprises is a tax stimulus, as it is aimed at encouraging entrepreneurial activity, but is not a tax benefit, as it does not create benefits for certain groups of taxpayers.

At the same time, it is fair to note that in the field of tax stimulus for innovation, tax stimulus may take the form of tax benefits, as they are aimed at a separate category of innovation-active taxpayers, which determines the interchangeability of terms.

Tax legislation does not answer the question of what a tax stimulus is and what phenomena are covered by this concept. Analysis of the provisions of the Tax Code of Ukraine [4] allows us to identify such categories that are endowed with signs of a tax stimulus. These are: special tax regime (Article 11), elimination of double taxation (Article 13), tax benefits (Article 30), postponement of the term of tax payment and collection or part thereof established by tax legislation to a later date (Article 32).

Thus, a tax stimulus may be proposed to define as a tool regulated by tax law, which influences on the behavior of the taxpayer and encourages being active (in economic and social relations, investment, innovation) through his or her economic interests to achieve a certain economic, social or other useful result.

Tax stimulus, that provides for the exemption of the obligated entity from tax liabilities, reducing their volume, as well as expanding its capacity to exercise tax rights, takes the form of tax benefits or other tax preferences and has certain characteristics (Figure 2).

From the economic point of view, tax stimulation is a set of measures to provide tax benefits and advantages to the subjects of economic relations, which create favorable conditions for them to carry out innovative activities.

O. Magopets argues that tax stimulation is a process of targeted influence of the state on taxpayers to ensure their interest in the activities encouraged by the state through the prospect of additional benefits and improve the financial and economic situation [5, p. 271]. According to R. Zhelizniak [6, p. 16], tax stimuli for innovation of enterprises are tax regulation measures to provide tax benefits to enterprises to encourage them to carry out and increase innovation, according to the relevant program.

In the conducted research, the subject of which is an agricultural enterprise, the tax stimulation for innovation may be proposed to define as the targeted influence of the state on taxpayers through the use of special methods and tax instruments to encourage businesses to implement research results using new methods, techniques or technologies to achieve a certain economic, social or other useful result.

Tax stimulation is a sub-function of tax regulation. It is known that tax regulation, as well as tax stimulation, is implemented in practice through the use of special tools means of tax policy.

In the modern theory of innovative development, there are different theoretical approaches to the classification of tax instruments, so Table 1 summarizes and presents the classification of tax stimulus for innovation based on the analysis of literature $[7 ; 8]$.

World experience shows that set of mostly applied tools of tax stimulus for innovation includes:

1) exemption from taxation of profits received from the implementation of innovative projects for a certain period;

2) reduction of income tax rates: reduction of income tax rates of innovative enterprises and organizations and reduction of tax rates on profits from the implementation of an innovative project;

3) preferential taxation of dividends received on shares of innovative organizations;

4) reduction of taxable income in the amount of the cost of devices and equipment transferred to higher education institutions, research institutes and other innovative organizations;

5) preferential taxation of profits resulting from the use of intangible assets; 
1. Tax stimuli are provided in the form of tax relations;

2. Tax stimuli are aimed at increasing the activities (traditional, investment, innovation) of certain entities;

$\sum \lambda \begin{aligned} & \begin{array}{l}\text { 3. Stimulation of taxpayers' interests is carried out through the use of special methods } \\ \text { and tax instruments; }\end{array} \\ & \text { and }\end{aligned}$

4. Tax stimuli are not necessarily selective (as they can be targeted as a separate group of taxpayers, as separate activities or as common to all);

5. Tax stimuli can be both tangible and intangible;

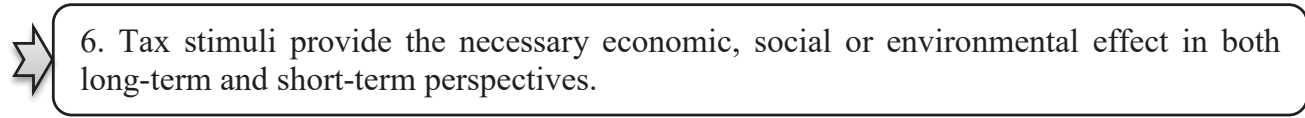

Figure 2. Characteristic features of tax stimulus

6) reduction of taxable income in the amount of contributions to special reserve funds;

7) accelerated depreciation;

8) reduction of the tax base by the amount of innovation costs of a capital nature (investment tax rebate);

9) deferred payment of income tax;

10) reduction of income tax liabilities (tax credit).

The provision of tax benefits is the most common form of stimulating innovation and, at the same time, the most controversial for Ukraine. Tax benefits are an important element in the tax system of any country, because their application is one of the ways to stimulate those activities or sectors of the economy that are currently a priority for the country's development, and the introduction of tax benefits involves other social economic effects.

According to Art. 30 of the Tax Code of Ukraine [4], tax benefit is provided by tax and customs legislation exemption of taxpayers from the obligation to accrue and pay taxes and fees in a smaller amount if there are certain grounds.

Classification of tax stimulus for innovation

\begin{tabular}{|c|c|}
\hline Classification feature & Classification group \\
\hline 1. By target orientation & $\begin{array}{l}\text { - Social; } \\
\text { - General economic; } \\
\text { - Investment; } \\
\text { - Innovative; } \\
\text { - Regulation of financial flows. }\end{array}$ \\
\hline 2. By functional purpose & $\begin{array}{l}\text { - Stimulating; } \\
\text { - Protective. }\end{array}$ \\
\hline 3. By target use of tax-exempt funds & $\begin{array}{l}\text { - Target; } \\
\text { - Non-target. }\end{array}$ \\
\hline 4. By scope & $\begin{array}{l}\text { - For individual payers; } \\
\text { - For certain activities; } \\
\text { - Mixed }\end{array}$ \\
\hline 5. By the subject of influence & $\begin{array}{l}\text { - Aimed at the end users (stimulating consumption); } \\
\text { - Aimed at businesses that are not end users (stimulating production and distribution). }\end{array}$ \\
\hline 6. By validity period & $\begin{array}{l}\text { - Tax Stimulus, the validity of which is not defined; } \\
\text { - Temporary. }\end{array}$ \\
\hline 7. By material property & $\begin{array}{l}\text { - Tangible; } \\
\text { - Intangible. }\end{array}$ \\
\hline $\begin{array}{l}\text { 8. By stage of the life cycle of } \\
\text { innovation processes }\end{array}$ & $\begin{array}{l}\text { - At the stage of fundamental research; } \\
\text { - At the stage of applied research; } \\
\text { - At the stage of research and development (R\&D); } \\
\text { - At the stage of innovation implementation; } \\
\text { - At the stage of consumption of innovation. }\end{array}$ \\
\hline
\end{tabular}


The grounds for granting tax benefits are features that characterize a certain group of taxpayers, their type of activity, the object of taxation or the nature and social significance of their expenses.

So, Yu. Ivanov [9;10] argues that "tax benefits are exceptions to the general rules of taxation, which allow the taxpayer to reduce the amount of tax (fee) payable, or exempt him or her from certain obligations and rules related to taxation". It should be noted that upon receipt of tax benefits, the taxpayer is exempt only from paying the relevant tax or fee. However, such an entity remains responsible for tax reporting and tax accounting.

It should be noted that all innovative benefits are divided into two groups [9, p. 252]:

1) direct benefits aimed at stimulating innovation activity;

2) indirect benefits aimed at other purposes, such as attracting investment, creating new jobs, etc., in the application of which the stimulation of innovation is one of the possible additional effects.

Development of national tax stimulation mechanism for innovation necessitates determination of their characteristics, and addresses the key issues that underlie the classification features, namely: to address the target of tax stimulus, the functional purpose of tax benefits, whether tax benefits will be used for to whom the tax benefits will be directed, what is the term of granting tax benefits, in terms of which elements of the tax will be provided preferential taxation and, in general, whether the tax benefits will be tangible in nature

An effective system of tax stimulus for the development of innovation in modern conditions can be built in compliance with the following fundamental points:

1) the choice of priority areas of innovation and a clear definition of the subjects to which the stimulus should be directed and which will be provided with tax benefits. Determining the exact parameters that must be met by recipients of tax benefits;

2) the choice of effective tools for tax stimulus for innovation. Tax instruments must meet the goals set by the state and the conditions inherent in the economic system within which they will operate. In this regard the assessment of the effectiveness of tax benefits is of particular importance;

3) improving the system of tax administration, which will make them less burdensome. The decisive role is also played by the wording of the preferential provision in the tax legislation, which excludes the abuse of tax benefits.

The Law of Ukraine "On Priority Areas of Innovation Activity in Ukraine" [11] defines strategic priority areas of innovation activity for 2011-2021, which provide technological renewal and development of the agro-industrial complex for the agricultural sector of Ukraine; widespread use of technologies for cleaner production and environmental protection, etc. This law and numerous other bylaws in Ukraine created a fairly solid legal framework, which not only provided for the general orientation and innovative development of the economy, but also outlined the main mechanisms for implementing such a course by the state.

Priority areas for innovative development, not only in the agricultural sector but also in other priority areas, need to be more specific. It is necessary to significantly reduce the list of priorities and focus only on the most important areas that will be able to make a "breakthrough" in innovation in Ukraine. And it is these priority areas that need significant state support.
Analysis of tax legislation to stimulate innovation shows that the mechanisms of preferential taxation have not found practical application due to imperfect tax legislation, due to the abuse of preferential terms by some subjects of innovation and investment activities and significant budget expenditures.

Despite the significant efforts spent on the development of the regulatory framework, it does not meet modern requirements, has little effect on the pace of development and does not encourage businesses to innovate. That is why the implementation of the Strategy of Innovative Development of Ukraine requires significant legislative changes regarding the state regulation of innovation processes in the country's economy. Of course, fundamental and applied R\&D requires significant financial costs, so they require significant direct support (informational, organizational and most importantly financial) of innovative enterprises, in which the state must also indirectly influence the encouragement of enterprises to innovate through tax Stimulus.

It should be noted that, unfortunately, the vast majority of agricultural producers, especially small and medium, are unable to innovate, due to improper development of innovation infrastructure and insufficient state support for innovation in the country is the degradation of scientific potential.

Agriculture is a specific, credit-intensive industry and less attractive for investment compared to other sectors of the economy. The reason for this is: firstly, the end result of agricultural producers depends on natural and climatic conditions; secondly, the production is seasonal, which affects the organization of labor in this area; thirdly, agricultural enterprises operate in conditions of risk and instability.

For a long time, the taxation of agribusiness was characterized by the presence of a special tax regime and the possibility of choosing a simplified system of taxation, which during 1999-2014 was represented by a fixed agricultural tax. After amendments to the tax legislation, it was transformed (almost unchanged) into a single tax of group IV.

It should be noted that until recently the tax policy of Ukraine was aimed at stimulating the development of agriculture, but since 2014 the tax burden on agricultural producers has increased significantly: rates of the single tax of group IV were increased 3 times; regulatory assessment of land should be indexed. In general, the transformations in the tax legislation on fat have only increased the tax burden on agricultural producers. Also, from 2018, the special VAT regime was completely abolished, which was a significant tax stimulus for agricultural development. Generally speaking, the agricultural sector has lost significant support for agricultural production from the state.

The choice of a simplified tax regime, despite the significant advantages that underpinned the reform of agriculture and the introduction of a mechanism of preferential taxation of agricultural producers, currently do not meet the requirements of socio-economic development of the country.

The tax system of our state for the whole period of its reform was characterized by constant changes of non-systemic nature. Transformation of the fixed agricultural tax into a single tax of group IV, the conditions of which have been significantly changed with a simultaneous increase in tax rates also has negative aspects for agricultural producers, which not only inhibits agricultural development but also limits its innovative capacity: firstly, a single the tax does not take into account production costs and the 
level of profitability of agricultural producers. Therefore, the amount of the single tax payable to the budget does not depend on the results of the agricultural enterprise; secondly, the calculation of the amount of tax liabilities depends on the regulatory monetary valuation of land.

A study of tax legislation shows that agricultural enterprises operate in a single tax environment, which does not take into account the level of their involvement in the innovation process. Agricultural enterprises only have the right to choose the general or simplified tax regime.

Based on this, tax stimulus for innovation in the agricultural sector of the economy should be aimed at all actors in the innovation process, so there are two directions: first direction is to stimulate (directly and indirectly) innovative enterprises of the agricultural sector (business incubators, agricultural clusters) to create an innovative product; second direction is the tax stimulus for agricultural enterprises that implement innovative processes in economic activity.

The vast majority of small and medium-sized agricultural enterprises select the simplified system of taxation, pay a fixed amount of tax, which does not take into account the financial results of the entity. Thus, the single tax of group IV is calculated based on the normative monetary assessment of agricultural land / water fund, tax rate and indexation coefficient. The single tax of group III depends on the amount of revenue (income) received from the implementation of its activities and the tax rate $(3 \%$ in the case of VAT payment, $5 \%$ in the case of inclusion of VAT in the single tax).

Today, there are many unsolved problems, but the most urgent among them is the selection of tax regime and elements of taxes that will form the basis for tax stimulation mechanism for innovation in agriculture. In Ukraine, there are significant reserves to improve the quality of fiscal authorities through the optimization of procedures, increasing automation and modernization of tax accounting, unification and improvement of document management and software, saving time, organizing tax advice to taxpayers and others.

Conclusions. World experience shows that there are a sufficient number of tax instruments to stimulate innovation. The problem remains that the government's measures to support the country's innovative development in the system of preferential taxation have not found broad practical implementation. The innovation policy pursued in the state provided for the provision of tax benefits and preferences only for innovative enterprises, while for ordinary agricultural enterprises, which are not included in the percentage criterion of innovation, the mechanism of tax stimulus is not provided.

Ukraine remains among the European countries with little state influence on innovation processes in the economy. At present, there is still insufficient financial support for innovative enterprises, but the mechanism of tax stimulation evolves and necessitates further scientific researches aimed on analysis of the experience gained in supporting innovation processes in the economy, carefully study gained results in stimulating innovation and find the most receptive methods to stimulate innovation, specify the priorities of our economy and improve the tax administration system, which undoubtedly plays a crucial role in intensification of innovative activity of agricultural enterprises.

\section{References:}

1. Reva D. M. (2015) Aktualjni pytannja podatkovogho stymuljuvannja [Current issues of tax stimulation]. Law and innovation, vol. 3(11), pp. 72-77.

2. Mazur Yu. O. (2016) Perspektyvy podatkovogho stymuljuvannja NDDKR v Ukrajini: dosvid innovacijno rozvynutykh krajin [Prospects for tax incentives for R\&D in Ukraine: the experience of innovatively developed countries]. Industrial Economics, vol. 2(74), pp. 33-48.

3. Bazylevych V. D. (2014) Ekonomichna teorija. Politekonomija: pidruchnyk [Economic theory. Political Economy: a textbook]. Kyiv: Knowledge. (in Ukrainian)

4. Verkhovna Rada Ukrainy (2010) Podatkovyj kodeks Ukrajiny vid 02.12.2010 no. 2755-VI [Tax Code of Ukraine dated 02.12.2010 no. 2755-VI]. URL: https://zakon.rada.gov.ua/laws/show/2755-17 (accessed 04.08.2020).

5. Mahopets O. A. (2014) Teoretychni pidkhody do vyznachennja sutnosti ponjattja "podatkove stymuljuvannja" [Theoretical app.roaches to defining the essence of the concept of "tax stimulation"]. Scientific works of Kirovograd National Technical University. Economic sciences, vol. 26, pp. 265-273.

6. Zhelizniak R. I. (2015) Podatkove stymuljuvannja innovacijnoji dijaljnosti pidpryjemstv [Tax stimulation for innovation of enterprises] (PhD Thesis), Lviv: Lviv Polytechnic National University.

7. Kyzym M. O., Kasianova L. V. (2012) Klasyfikacija instrumentiv podatkovogho stymuljuvannja innovacij [Classification of instruments of tax stimulation of innovations]. Problems economy, vol. 4, pp. 23-29.

8. Turianskyi Yu. I., Kolomiichuk N. M., Havrylko P. P. (2011) Klasyfikacija ta vydy podatkovykh piljgh [Classification and types of tax benefits]. Scientific Bulletin of the National Forestry University of Ukraine, vol. 21.9, pp. 272-275.

9. Ivanov Yu. B., Maiburov I. A. (2010) Podatkova polityka: teorija, metodologhija, instrumentarij [Tax policy: theory, methodology, tools]. Kharkiv: INZhEK. (in Ukrainian)

10.10 Krysovatyi A. I., Vasylevska H. V. (2013) Novitnja paradyghma preferencijnogho opodatkuvannja: monoghrafija [The latest paradigm of preferential taxation: a monograph]. Kyiv: CUL. (in Ukrainian)

11. Verkhovna Rada Ukrainy (2011) Zakon Ukrainy "Pro priorytetni naprjamy innovacijnoji dijaljnosti v Ukrajini" vid 08.09.2011 no. 3715-VI [Law of Ukraine "About priority directions of innovative activity in Ukraine" dated 08.09.2011 no. 3715-VI]. URL: https://zakon.rada.gov.ua/laws/show/3715-17 (accessed 04.08.2020).

12.Labunska S., Karaszewski R., Prokopishyna O., Iermachenko I. (2019) Cognitive analytical tools for cost management of innovation activity. Problems and Perspectives in Management, vol. 17(1), pp. 395-407.

13.Labunska S., Petrova M., Prokopishyna O. (2017) Asset and cost management for innovation activity. Economic Annals-XXI, vol. 165(5-6), pp. 13-18.

14.Prokopishyna O. V., Koptieva O. V (2017) Shljakhy aproksymaciji jevropejsjkogho dosvidu stymuljuvannja innovacijnoji dijaljnosti do realij Ukrajiny [Ways to app.roximate the European experience of stimulating innovation to the realities of Ukraine]. Scientific Bulletin of Kherson State University. Economic Sciences Series, vol. 27, pp. 80-92. 


\section{Список використаних джерел:}

1. Рева Д.М. Актуальні питання податкового стимулювання. Право та інновації. 2015. № 3(11). С. $72-77$.

2. Мазур Ю.О. Перспективи податкового стимулювання НДДКР в Україні: досвід інноваційно розвинутих країн. Економіка промисловості. 2016. № 2(74). С. 33-48.

3. Базилевич В.Д. Економічна теорія : Політекономія : підручник / за ред. В.Д. Базилевича. Київ : Знання, 2014.710 с.

4. Податковий кодекс України від 02.12.2010 p. № 2755-VI. Дата оновлення: 01.08.2020. URL: https://zakon.rada.gov.ua/ laws/show/2755-17 (дата звернення: 04.08.2020).

5. Магопець О.А. Теоретичні підходи до визначення сутності поняття «податкове стимулювання». Наукові праці Кіровоградського національного технічного університету. Економічні науки. 2014. Вип. 26. С. $265-273$.

6. Желізняк Р.Й. Податкове стимулювання інноваційної діяльності підприємств : дис. ... канд. ек. наук : 08.00 .08 / Національний університет «Львівська політехніка». Львів, 2015. 225 с.

7. Кизим М.О., Касьянова Л.В. Класифікація інструментів податкового стимулювання інновацій. Проблеми економіки. 2012. Вип. 4. С. 23-29.

8. Турянський Ю.І., Коломійчук Н.М., Гаврилко П.П. Класифікація та види податкових пільг. Науковий вісник Національного лісотехнічного університету України. 2011. Вип. 21.9. С. 272-275.

9. Іванов Ю.Б., Майбуров І.А. Податкова політика: теорія, методологія, інструментарій : навч. посіб. Харків : ІНЖЕК, 2010. 492 с.

10. Крисоватий А.І., Василевська Г.В. Новітня парадигма преференційного оподаткування : монографія. Київ : ЦУЛ, 2013. $260 \mathrm{c}$.

11. Про пріоритетні напрями інноваційної діяльності в Україні : Закон України від 08.09.2011 № 3715-VI. Дата оновлення: 05.12.2012. URL: https://zakon.rada.gov.ua/laws/show/3715-17 (дата звернення: 04.08.2020).

12.Labunska S., Karaszewski R., Prokopishyna O., Iermachenko I. Cognitive analytical tools for cost management of innovation activity. Problems and Perspectives in Management. 2019. № 17(1). P. 395-407.

13. Labunska S., Petrova M., Prokopishyna O. Asset and cost management for innovation activity. Economic Annals-XXI. 2017. № 165(5-6). P. 13-18.

14.Прокопішина О.В., Коптєва О.В. Шляхи апроксимації європейського досвіду стимулювання інноваційної діяльності до реалій України. Науковий вісник Херсонського державного університету. Серія «Економічні науки». 2017. № 27. С. 80-92. 